REVIEW ARTICLE

\title{
Performing developmental tasks in emerging adults with childhood parentification - insights from literature
}

\author{
Judyta Borchet ${ }^{A, B, E, F}$, Aleksandra Lewandowska-Walter ${ }^{A, B, E}$, Teresa Rostowska ${ }^{A, E}$ \\ Institute of Psychology, University of Gdańsk, Poland
}

Parentification is the process of role reversal between the child and the parent, whereby the child provides support and acts as the caregiver for the parent, instead of being supported and taken care of. The phenomenon of parentification may afflict families at diverse stages of development, including those before as well as after the phase of empty nest. Parentification may then pertain a threat to the development of a young person by impeding or preventing him or her from fulfilling developmental tasks. Furthermore, it can be a distracting factor in his/her future role as a partner, parent, or employee. The purpose of this review is to examine the current literature concerning the effects of retrospective parentification on young adults' difficulties in performing developmental tasks and roles.

KEY WORDS

retrospective parentification; young adults; reversing family roles; social roles

CORRESPONDING AUTHOR - Judyta Borchet, Institute of Psychology, University of Gdańsk, 4 Bażyńskiego Str., 80-309 Gdańsk, Poland, e-mail: judyta.borchet@gmail.com

AUthors' Contributions - A: Study design - B: Data collection - C: Statistical analysis - D: Data interpretation .

E: Manuscript preparation · F: Literature search · G: Funds collection

to Cite this ARTICLE - Borchet, J., Lewandowska-Walter, A., \& Rostowska, T. (2018). Performing developmental tasks in emerging adults with childhood parentification - insights from literature. Current Issues in Personality Psychology 6(3), 242-251.

RECEIVED 02.10.2017 · REVIEWED 28.10.2017 · ACCEPTED 31.01.2018 · PUBLISHED 30.05.2018 


\section{BACKGROUND}

Developmental concepts assigning particular tasks and roles to early adulthood lose their relevance in modern society (Baumann, 2008). After interviewing 300 young people Arnett noticed that all of them reported the "feeling of being in-between", not a child but not having adult responsibilities like marriage, parenthood, or a stable job yet. Therefore, he proposed a new period of life-span development that he called "emerging adulthood" (Arnett, 2004). Post-industrial societies do not define unambiguous expectations towards young people, therefore they may enjoy freedom of choice in terms of deciding on professional activity, entering into relationships and formalising them, and whether or not they want to become parents (Arnett, 2000; Baumann, 2008). However, the lack of a generally imposed "recipe for life" does not mean that the developmental tasks listed by theoreticians are entirely outdated. It is rather the time point of their performance that has become flexible due to the prolonged time of coming to adulthood in comparison to previous generations, for example, due to the possibility of education, migration, and gaining professional qualifications (Ziółkowska, 2005). Furthermore, young people enjoy a broader range of choices in respect of the roles they perform: for example, marriage alternatives such as consensual union, or even giving up on an intimate relationship and remaining single. Prior to taking up a full-time job, they can prolong their time spent on education or part-time work, or - referring mostly to people with high socio-economic family background status - remain financially dependent on their families (Gurba, 2002).

Parentification is a term introduced by Boszormenyi-Nagy (1973). The author defined his concept as a situation where the children or adolescents perform adult roles even though they are not emotionally and developmentally ready to deal with those challenges (Boszormenyi-Nagy \& Spark, 1973). In this pattern of family interactions, the child (also as an adult) provides care and support towards his/ her parent instead of receiving it from the parent (Jurkovic, 1997; Hooper, Marotta \& Lanthier, 2008; Hooper, DeCoster, White, \& Voltz, 2011; Schier, 2010, 2014). The phenomenon of parentification appears when, due to a family system disadvantageous for the child, the child must shoulder a burden of responsibilities, so that he/she is unable to entirely engage into his/her own developmental tasks (Jurkovic, 1997; Hooper, 2007; Schier, 2010; Rostowska \& Borchet, 2016; Borchet \& Lewandowska-Walter, 2017). Research on young adults indicates various outcomes of parentification. The problems may appear in many areas of life and can result from failures in performing developmental tasks (such as work, cre- ating a relationship, and shaping one's identity). It is worth taking a look at the extent to which the experience of parentification inhibits or precludes taking them up, and whether it happens more often than in people who do not experience parentification. The main developmental task in emerging adults is shaping the identity, what is based on two main processes - exploration and commitment (Arnett, 2000; Erikson, 1963). These processes are hindered while experiencing parentification. One is unable to explore identity and prematurely commits to the set of values expected by his or her parents (Fullinwider-Bush \& Jacobvitz, 1993). The body of literature on parentification is still insufficient (see: Byng-Hall, 2008; Shaffer \& Madden, 2016). Further research with emphasis on intercultural factors is required (Hooper, 2014). This review is therefore not chronologically structured. The agenda of the review is based upon Erikson's theory of psycho-social development, which allows examination of the impact of retrospective parentification on the performance of subsequent social roles by young adults.

According to Erikson's (1963) theory of psycho-social development, each stage of human life involves resolving relevant crises and executing particular developmental tasks. The experience of parentification may interfere with the performance of tasks at every stage of development, even when the adult child has already left the family home or intends to do so in the near future. The research of literature hitherto has instead examined the situation of children and adolescents experiencing parentification, who are still living in family households. This review, however, focuses attention on how past experience of parentification may distort the normative order of events within the family in the context of young adults performing their social roles consistent with the stage of development in the frame of Erikson's theory.

\section{PARENTIFICATION - TYPES AND CONSEQUENCES}

The most widely known classifications of parentification concern its mode (Jurkovic, 1997) and possible outcomes (Chase, 1999). The distinction made by Jurkovic (1997) identifies emotional and instrumental parentification. The emotional subtype of parentification requires the child to fulfil social and emotional needs of other members of the family. The child must then devote him/herself to maintaining a good family atmosphere. Concern for the emotional needs of parents or siblings can be expressed, for example, by caring for their well-being and being alert to their moods. In the case of instrumental parentification, the main concern of the child is taking care for the family's living conditions (Hooper et al., 2008; Hooper \& Wallace, 2010; Hooper, Doehler, \& Han- 
nah, 2011; Schier, 2010, 2014). In such a situation, the child provides family support by taking care of the general logistics of running a household and his/her own physical work (e.g. cleaning, cooking, laundry, shopping, taking care of his/her siblings, or earning money).

Some researchers believe that instrumental parentification is less of a threat to the child than emotional parentification (Hooper et al., 2008). It should be noted, however, that Jurkovic's (1997) distinction of parentification types are not mutually exclusive. Children may perform many different roles in the family at the same time, so both parentification dimensions (emotional and instrumental) can occur simultaneously (see Schier, 2010).

Chase's (1999) classification of parentification focuses on the consequences of experienced parentification, which may be positive or negative. Thus, the author distinguishes constructive (adaptive) and destructive (pathological) parentification. A situation that is beyond the child's capabilities and its comprehensive resources often results in numerous negative consequences. A meta-analysis of the studies on this phenomenon revealed that parentification is connected with anxiety disorders, personality disorders, and eating disorders (Hooper et al., 2011b). Literature reviews indicate that the phenomenon of parentification is associated with increased use of psychoactive substances (Chase, Demming, \& Wells, 1998), mental disorders (Jones \& Wells, 1996 after: Hooper et al., 2008), difficulties in relationships (Valleau, 1995 after: Hooper et al., 2008), posttraumatic stress disorder (Cicchetti, 2004), and poor parental skills in adulthood (Boszormenyi-Nagy \& Spark, 1973; Chase et al., 1998). People who have experienced parentification are more likely to repeat the abnormal patterns of relationship and hierarchy within their own family because parentification is transmitted between generations (Schier, 2010, 2014).

Parentification may also allow the child to develop self-reliance despite emotional or physical stress (see Chase et al., 1998; Hooper et al., 2008). It is important to note that in the case of constructive parentification, the family expresses gratitude towards the child and appreciates him/her for taking care of other members of the family system. Performing certain functional responsibilities and roles adapted to his/ her capabilities affects the emotions of the child, who feels needed, loved, and important. It frames his/her sense of competence and perception of self-agency and shapes future target-oriented action strategies (Schier, 2014). Reversing the roles with parents can foster the development of relationship-building competencies because children need to devote their time and attention to one another, and learn responsibility and how family members should care for each other (Gladstone, Boydell, \& McKeever, 2006; Hooper et al., 2008). Parentification can also help frame resistance to adversity, i.e. resilience. This type of psychic resistance is associated with functional coping strategies, healthy mental development, and the ability to shape healthy emotional bonds (Hooper et al., 2008).

Literature review indicates the need to distinguish between parentification and related processes that may be very similar or even overlapping. Terms such as "parentified child", "parental child", or "adult child" are often treated as synonyms (see: Schier, 2014). However, some researchers consider them as different processes that have different consequences for the development of the child. For example, Stephanie Haxhe distinguishes three processes related to parentification - adultisation, parentalisation, and delegation - due to the parent's expectations for the child, the child's needs, the type of burden for the child, its relevance to the child's competencies, perception of the child's dedication to the family, and the context (see more: Haxhe, 2016).

The literature review allows us to follow the differences in defining the phenomenon of parentification by different authors. Some researchers decided to avoid pathologising connotations of the term parentification and replaced it with the neutral term filial responsibility (see: Jurkovic et al., 2004; Kuperminc, Jurkovic, \& Casey, 2009). That term refers to the intensity of children's family caregiving efforts (Jurkovic et al., 2004). Other researchers define only emotional responsibilities and burden as parentification, explaining that "instrumental responsibilities without emotional burden don't lead to parentification" (Haxhe, 2016, p. 4). However, another researcher, Lisa Marie Hooper, in her model of parentification pays attention to whom the child is taking care of: his/her parents and/or siblings, not the type of child's responsibilities (emotional vs. instrumental) (Hooper et al., 2011a). The authors of this article share Hooper's view of parentification because emotional and instrumental parentification often co-exist (i.e. Schier, 2014). Moreover, being physically overburdened may also affect the child's self-esteem and mood. That is why the further paragraphs presented beneath include various examples of childhood parentification and its outcomes in early adulthood without dividing them by its type.

\section{EMERGING ADULTS AND RETROSPECTIVE PARENTIFICATION}

There are many typologies of the periodisation of stages in human development. Late adolescence is understood as the period from about 16 to about 20 years (Obuchowska, 2002), whereas early adulthood is rated between 20-23 and 35-40 years (Gurba, 2002). Therefore, there is a fine line between late adolescence and early adulthood, and it is often contractual. One of the most famous theories of psycho-so- 
cial development of the human throughout his/her lifespan is Erikson's theory (1963), which identifies eight stages of human development. At each stage, the individual experiences a particular type of developmental crisis that needs to be resolved. A successful completion of the crisis determines passing through to the next development phase. If a challenge of a stage is not successfully completed, it may be expected to reappear as problems in future life.

According to Erikson (1968), the most crucial task of adolescence (12-18 years old) is to achieve an integrated and coherent sense of self, constituting the individual's identity. If the individual does not master this crisis between identity and role confusion, it may result in uncertainty about the self-image and involves the individual not being sure about his/her place in society. In turn, during emerging adulthood (19-30), the key task is to form intimate partnerships. At this age the individual explores love, understood as the ability to care for others. Young adults are also faced with the developmental conflict between the need for intimacy and isolation. Not mastering this stage can lead to loneliness and isolation from society. The successful completion of this and previous developmental stages allow the individual to create stable relationships (marital roles) as well as parenting (parental roles) and other social roles (i.e. as an employee or citizen) (Erikson, 1968).

Other theoreticians and human development researchers state similar tasks young adults have to face. According to Birch (2005), at this stage of life young people focus on individual development in the context of their social functioning and relationships. The individual determines his/her identity and takes on new social roles (the employee, the parent, and the spouse) (Birch, 2005). Havinghurst (1981 after: Ziółkowska, 2005), however, as the developmental responsibilities relevant for early adulthood, indicates the choice of a spouse, learning how to live with him/ her, setting up a family, running the household, getting a job, and exercising civil duties. Recently, the cultural changes demand to distinguish a specific developmental period between childhood and adulthood where individuals have not tried to make commitments of adult life but are becoming increasingly independent from their parents. That is where the term "emerging adulthood" came from. It describes a developmental state that extends from the late adolescence through one's twenties (Arnett, 2004). There are five features of emerging adulthood being distinguished: (a) exploration in relationships and occupation; (b) instability; (c) self-focus; (d) feelings of being in-transition, such as not being a child but not yet an adult; and (e) consideration of possibilities for one's future (Arnett, 2004). Emerging adults have the opportunity to leave a parentified environment and separate from their parents. Moreover, in emerging adulthood people are no longer considered to be children, so the roles that they perform within their families are no longer considered as developmentally inappropriate (Arnett, 2006). Therefore, emerging adults are an interesting group in which to examine the outcomes of parentification.

Concluding, the developmental theories stated above place the key roles and developmental tasks of emerging adults within the area of intimate relationships, parenting, and work.

\section{DISTORTIONS IN THE SEPARATION- INDIVIDUATION PROCESS}

The phenomenon of parentification affects families at all stages of their developmental cycles, including those families with children coming to adulthood - adolescents and young adults. Adolescence constitutes a challenge for the family system because family loyalty bonds are verified at this time (Wolska, 2000). Family loyalty is an invisible network of relationship bonds that are based on the rules applied within the family and make it possible to survive. The family would not be able to exist in the form of a relationship if its members were not loyal to the people who gave them life. Loyalty is a sense of solidarity and commitment to the relatives (Boszormenyi-Nagy \& Spark, 1973; Wolska, 2000). It is manifested through the repetition of family relations patterns by successive generations, passing along family myths or the similarity of family rituals (Boszormenyi-Nagy \& Spark, 1973). In late adolescence, conflicts in this area are most frequently encountered. Young adults leave the family home, enter into partnerships, and become independent, which can be perceived by some parents as a threat to the existing balance of the family system.

A shift in the relationship between an adolescent child and a parent is essential in order to change adolescence into adulthood by weakening the child's dependency degree and his/her self-creation. The separation-individuation process can, however, be disturbed by the inter-generational transfer reversing the hierarchy in the family, resulting in parentification. The separation process will not be conducted accurately if the child is made to feel guilty that the family system will not be capable to work without him/her, which is the case in families where the phenomenon of parentification occurs (Radziwiłłowicz, 2015). Some parents expect that a parentified adolescent child will express his/her loyalty towards them by staying in their existing family and not changing the strength and quality of the relationships, which overburdens a young person to individuate his/her developmental stage (Wolska, 2000). The parentified teenager develops a sense of "false self" (Wells, Glickauf-Hughes, \& Jones, 1999), which impedes the performance of his/her developmental tasks congruent 
for the adolescence period, and primarily the separation from his/her parents. Another reason why they have difficulties with boundary dissolutions may be the fact that the experience of childhood parentification may hinder identity development in young adulthood due to less identity exploration, especially in terms of interpersonal relationships (Fullinwider-Bush \& Jacobvitz, 1993). Failure in the process of separation-individuation is a risk factor for the occurrence of psychopathology, which may result during adolescence and later life in internalisation disorders (e.g. depression), externalisation disorders, and behavioural and personality disorders (Jurkovic, 1997; Byng-Hall, 2008; Hooper et al., 2008; Hooper et al., 2011b), manifested in, for example, self-destructive tendencies in the form of self-harm or suicide attempts and eating disorders (Namysłowska, 2011; Radziwiłłowicz, 2015).

\section{ADVERSITIES IN ACTING AS SPOUSE AND PARENT}

The experience of parentification acts in two ways as a threat to the family that the parentified person will start in his/her future life: by delaying the performance of a matrimonial or parental role or, once the person has already established a family, threatening the newly formed family system due to the process of transferring patterns of family roles (intergenerational parenting transmission).

Parentification imposed in late adolescence by the family of origin may delay or distort the development of new roles relevant to his/her developmental stage, i.e. the role of the partner, the spouse, and eventually the parent (Wolska, 2000; Schier, 2010). The term "family role" is most often used to describe patterns of behaviour (or ideas about them) that we undertake in social situations related to the functioning of the family. First of all, departing from the parents may inflict a sense of guilt in late adolescent, which lowers his/her capability of emotional involvement in his/her own relationship (Wolska, 2000). Secondly, the parentified young adult, despite starting his/her own family, may still be burdened with obligations imposed by his/her parents, so he/she cannot entirely devote him/herself to his/her own family (de Barbaro, 1994; Wolska, 2000).

The young person may, however, respond oppositionally towards family expectations. The more intense is his/her connection with the family environment, the stronger is his/her will to resist the bonds, and sometimes it even becomes a struggle for emotional isolation from the loved ones (Bowen, 1978). This is necessary to reconcile the previous vertical loyalties that bind him/her to the family and the horizontal loyalties that connect him/her with peers and life partners. The necessity of choosing between these two loyalties may cause crises in relationships or even lead to breaking off contact with the family. Finally, the experienced conflict may expose itself in mental disorders (Wolska, 2000).

If the conflict of loyalty is not solved, it is transferred to the family of procreation. In this situation, it becomes a source of tension between the spouses. Departing from parents can be a source of guilt feelings. For this reason, a young person has fewer emotional opportunities to engage in his/her own relationship, which will be noticed by the partner and recognised as a lack of interest in him/her (Wolska, 2000). Furthermore, there may be a situation in which a young person is caught up in conflict with his/her family and compensation for past mistakes to the extent that he/she will not be capable to make commitments to his/her partner and children (Wols$\mathrm{ka}, 2000)$.

A parentified young adult, despite starting his/ her/her own family, may still be so burdened with obligations towards his/her parents that he/she will not be able to entirely devote him/herself to his/her own family. Parentification imposed by the family of origin disturbs functioning as a partner (Macfie, McElwain, Houts, \& Cox, 2005), spouse or parent (cf. Shaffer \& Egeland, 2011; Nuttall, Valentino, \& Brokowski, 2012; Wolska, 2000). The second way in which parentification threatens the family of a person who has experienced it is through transmission between generations. Parentification sources origins from three generations ago, which means that this phenomenon has to be considered in the context of grandparents, parents, and children, even if they have already become adults. According to this presumption, parents may repeat the patterns of behaviour that they have been subjected to by the child's grandparents. Another generation, by taking care of his/her parents, compensates the "debt", which is related to old traumas involving other family members (Schier, 2010). The pattern of requirements for care from one's own children is repeated by the person who him/herself as a child had to bear responsibility for his/her family members (Barnett \& Parker, 1998; Schier, 2014).

The body of literature also includes reports on maternity decision making by women who have experienced parentification. The results of this study are ambiguous. Marshall (1993, after: Barnett \& Parker, 1998) in her book Not having children postulated that such women voluntarily give up on maternity (voluntary childlessness), which is caused by their negative image of parenting, childhood experiences, being overly responsible for the family, and often being the eldest of siblings. However, her research did not confirm this theory, which she explained with the complexity of the problem. Still, Marshall's idea is still a living issue (Barnett \& Parker, 1998). A similar approach was presented by Kaltreider and Margolis (1977, after: Lackie, 1983), who in 1977 stated that 
people who have experienced parentification may choose to be childless.

The experience of parentification in the family of origin threatens therefore not only the family of procreation, but also the bonding with the family of origin. The departure from the family system may take the form of not only separation, but also a complete escape, which refers particularly to rejected, abused, and used children (Radziwiłłowicz, 2015). One of the forms of emotional separation from the family of origin and physical distancing from the family home may be the escape of a young person into a marriage (Barnett \& Parker, 1998). Girls who, due to family responsibilities, had a low attendance at school not only suffer from insufficient level of education or challenges on the employment market, but are also more likely to face adolescent pregnancies, unsatisfactory marriages, and difficulties in raising their children (Barnett \& Parker, 1998).

Furthermore, taking on an inadequate care role in a family of origin may affect the choice of romantic partners in the future. The experience of emotional parentification in childhood is negatively related to the quality of communication in the romantic relationships of young adults and positively related to the occurrence of conviction revealing a lack of sense of security in close relationships (Shaffer \& Madden, 2016). These individuals may act as self-sufficient people and seek partners who are similar to their parents, i.e. needy, demanding their care and concern (Barnett \& Parker, 1998; Byng-Hall, 2008). The described mechanism of partner selection by individuals who have experienced parentification is consistent with the concept of collusion (Willi, 2014). This is an unconscious phenomenon where partners are complementary to each other, whereby their partner selection criteria are based upon their unresolved issues, e.g. one of the partners is dominant and the other is subordinate. Moreover, the distortion in the process of shaping the identity may also affect choosing the partner. Due to unconscious motives (such as unmet childhood needs) the person does not sufficiently explore (escape into a relationship or marriage) or does not undertake any exploration because of loyalty and their obligation towards the parents (the decision about being in a relationship).

\section{ADVERSITIES IN ACTING AS STUDENT AND EMPLOYEE}

Experience of parentification in the family of origin results in a lower level of education in the future (Chase et al., 1998). Persons who are burdened with fulfilling the requirements and needs of family members find it difficult to meet their academic responsibilities and thus achieve results below their predispositions (underachievement). Such difficulties may reflect problems at the level of the family system and not pertain to symptoms of, for example, maladjustment or lack of involvement in learning. It would be very interesting to carry out research for analogous mechanisms within the group of adults already in the work environment and to analyse whether people who have experienced high levels of parentification towards parents/siblings along with the negative consequences of this phenomenon also face issues with job performance and career paths. This theory is consistent with the assumption that the imbalance between family requirements and work is the cause of the labour-family conflict, resulting in lower level of feelings of satisfaction with life (Rostowska, 2008).

At the same time, it must be noted that school may constitute in the life of a young person an area in which he/she is experiencing success, encouraging him/her to form proper relationships with teachers and peers and receiving support from them. These factors enable the development of resilience in an adolescent despite difficult family experiences (Barnett \& Parker, 1998).

On the other hand, the past experience of parentification may direct a person to become involved in professional development at the expense of family roles. A study by Fullinwider-Bush and Jacobvitz (1993) found that the mother-daughter dissolution was associated with the daughter's tendencies to commit herself prematurely to a career and relationships based on a simple acceptance of parental expectations and values. Additionally, father-daughter dissolution resulted in a lower level of commitment to beliefs and values about work, romantic relationships, and friendship. A similar mechanism has been examined in studies involving young, childless adults conducted by Black and Sleigh (2013). Participants with a high sense of injustice in relation to their childhood parentification also ranked career as a more important priority than caring for their future spouse or children. According to the authors of the study, these participants may be attempting to compensate for the unfairness they experienced in their childhood home, as lower family income is one predictor of parentification (Black \& Sleigh, 2013). This idea is consistent with the hypothesis of scarcity - one of the materialism explanations. According to it, by striving to possess money, fame, and success, people compensate for the deprivation of economic needs and the need for the sense of safety from their childhood (Zawadzka \& Lewandowska-Walter, 2016).

Families with low socio-economic status are particularly vulnerable to the occurrence of the parentification phenomenon (Lackie, 1983; Burton, 2007; Hooper et al., 2011a; Hooper et al., 2011b; Schier, 2014). Insufficient economic resources of the family are conducive to the development of premature adulthood (pseudomaturity) based upon street-wisdom 
(street-wise), which helps the child to develop survival strategies in difficult environments (Lackie, 1983). Apart from the difficulties in earning a living, a low socio-economic status of the family affects its daily life, which may cause children to become subjected to parentification. First of all, a lack of money forces parents to take up jobs with long hours because they strive to improve the family's financial situation. Simultaneously, due to a lack of funds, the family is unable to provide paid care for the children at that time. For this reason, children are burdened with taking care of the home and their siblings (Burton, 2007). On the other hand, families in financial distress may face housing difficulties, where the family members may lack privacy (for example due to a small apartment or flat shared with grandparents - authors' note). In such a situation, it is easy to expose children to sensitive adult matters (Burton, 2007). It is important to note that young people and children, in an effort to support the family's difficult financial situation, can quickly take up their first job (Burton, 2007). Premature child labour is a manifestation of instrumental parentification (see Jurkovic, 1997; Hooper et al., 2008; Hooper et al., 2011a; Schier, 2010, 2014).

The experience of parentification may also influence the choice of any professional pathway connected with helping others (Lackie, 1982, 1983; ByngHall, 2008). Therapists often perform a parental role towards their patients (Byng-Hall, 2008). Acting in the role of a caring and "good" child for all the family members is related to professional work later in life, as demonstrated by studies involving social workers. Of 1577 American social workers who participated in Lackie's research, over two thirds confirmed that they had experienced different forms of parentification in their families (1982). Providing care for family members can lead to a choice of professional life in which the person "heals" other families because he/she was not capable of fixing his/her or her own family (Lackie, 1983). A social worker may even experience symbolic gratification and reduce his/her own sense of lack of care by identifying with the client he/she is helping (Lackie, 1983). On the other hand, the patient's past parentification experience can sensitise the therapist to the processes taking place in the family (Byng-Hall, 2008), and the supervision may assure the correctness of the therapy process.

\section{CONCLUSIONS AND FUTURE RESEARCH}

At various stages of life, a person can perform many roles at the same time, such as the role of his/her parents, sibling, student, employee, spouse, or parent. However, some of these roles are more important or more typical for a given period of life, and therefore a person undertakes particular developmental tasks
(Rostowska, 2008). Emerging adults who experienced parentification during childhood (and may still be enmeshed with their families) may undertake developmental tasks prematurely, procrastinate, or not implement them at all as well as have difficulties with exploring their identity and commit to certain values prematurely or insufficiently (Fullinwider-Bush \& Jacobvitz, 1993). Additionally, in his concept of "emerging adulthood" Arnett (2006) underlines that it is the age of identity exploration. This means that the childhood experience of parentification may lead to a breach of the timeliness norm for developmental tasks in early adulthood. This norm assumes that in the course of the development of the family and its members certain developmental tasks should be implemented within a certain period of time, with respect to the social norms (Wojciechowska, 2011). Due to the overburdening by the preoccupation of the family system, the individual cannot fulfil the developmental tasks of late adolescence, i.e. separation from the family system (see Namysłowska, 2011). Thus, at a later time, he or she is unable to fulfil a socially sanctioned sequence of life events in a timely manner: getting education - getting a job - starting a family. Transgression of the normative order of events in the family can lead to disturbances in the way of life of the young person and his/her entire family (Wojciechowska, 2011; Klein \& White, 1996). In the life of a young person, work and education can become a kind of escapee from everyday life and chores (Black \& Sleigh, 2013). On the other hand, the role of the caregiver of the family may preclude the person's educational development (Chase et al., 1998). For this reason, these individuals may face particular difficulties in achieving a familywork balance. According to the assumptions of the socio-ecological model of health (as well as roles), the achievement of a dynamic state of balance, which is one of the sources of mental health, is possible when there is a correct relationship between the various spheres of life (and the roles). Disorder in one area of a person's life leads to distraction in another (Sęk, Ścigała, Beisert, \& Bleja, 1992). Therefore, it can be expected that people experiencing parentification are particularly exposed to labour-family conflict. This area requires special attention from researchers because the capacity to balance family and work life affects the quality of human life (cf. Peplińska \& Rostowska, 2013). Similarly, Ziółkowska (2005), who distinguished work, family, and leisure as the three main areas of activity of young adults, emphasises that in order for a young person to experience a high quality of life, his/her identity must be based on at least two of these three spheres. This gives young adults the opportunity to select from a variety of resources in difficult situations, as well as to develop social, psychological, and physical security and a sense of stability (Ziółkowska, 2005). 
Notwithstanding that it is difficult to unequivocally determine the moment of reaching maturity (Gurba, 2002), it is well known that flexibility in performing many roles simultaneously is a manifestation of human maturity (Bańka, 2005; Rostowska, 2008). When a young person experiences parentification and is not capable of taking on suitable developmental roles and responsibilities due to excessive engagement into family issues and its members, he/she cannot achieve maturity.

The experience of parentification can have different outcomes for the psycho-social development of an individual. Numerous factors determine whether they will be more or less negative; factors such as the age of the child, the person the child is caring for, the duration of the parentification process (Schier, 2010), followed by the type of work the child performs or the family's approach to talking about the child's tasks (Jurkovic, 1997). Therefore, a straightforward answer whether the experience of parentification may completely preclude or only hinder young adults from taking up social roles relevant to their stage of development is not easy to state. According to the authors, the answer to the question about the outcomes of parentification is aptly concluded by Barnett and Parker (1998, p. 146): "The final outcome for any individual will be judged at the end of his/her life-span and the judgment will be largely subjective". After the literature review we recommend that in the future, research should put a special emphasis on the analysis of the mechanisms responsible for taking up the role of an adult in the family by a child, in which individual differences, personality traits, and the mechanisms of shaping the identity (exploration and commitment) would explain the diversity of the consequences of parentification.

\section{REFERENCES}

Arnett, J. J. (2000). Emerging adulthood: A theory of development from the late teens through the twenties. American Psychologist, 55, 469-480.

Arnett, J. J. (2004). Emerging adulthood: The winding road from the late teens through the twenties. New York, NY: Oxford University Press.

Arnett, J. J. (2006). The psychology of emerging adulthood: What is known and what remains to be known. In J. J. Arnett \& J. L. Tanner (Eds.), Emerging adults in America: Coming of age in the 21st century (pp. 303-330). Washington, D.C.: American Psychological Association.

Bańka, A. (2005). Jakość życia a jakość rozwoju. Społeczny kontekst płci, aktywności i rodziny [The quality of life and the quality of development. Social context of sex, activity and family]. In A. Bańka (Ed.), Psychologia jakości życia
[Quality of life psychology] (pp. 11-78). Poznań: Stowarzyszenie Psychologia i Architektura.

Barbaro de, B. (1994). Wprowadzenie do systemowego rozumienia rodziny [Introduction to understanding the family system theory]. Kraków: Collegium Medicum UJ.

Barnett, B., \& Parker, G. (1998). The parentified child: early competence or childhood deprivation? Child Psychology and Psychiatry Review, 3, 146-155.

Baumann, Z. (2008). Wspólnota. W poszukiwaniu bezpieczeństwa w niepewnym świecie [Community. In search of safety in insecure world]. Kraków: Wydawnictwo Literackie.

Birch, A. (2005). Psychologia rozwojowa w zarysie [Developmental psychology in brief]. Warsaw: Wydawnictwo Naukowe PWN.

Black, B. T., \& Sleigh, M. J. (2013). Relations among parentification, parenting beliefs, and parenting behaviors. Journal of Student Research, 2, 52-57.

Borchet, J., \& Lewandowska-Walter, A. (2017). Parentification - its direction and perceived benefits in terms of connections with late adolescents' emotional regulation in the situation of marital conflict. Current Issues in Personality Psychology, 5, 113-122. DOI: 10.5114/cipp.2017.66092

Boszormenyi-Nagy, I., \& Spark, G. (1973). Invisible loyalties. New York: Harper and Row.

Bowen, M. (1987). Family therapy in clinical practice. New York: Jason Aronson.

Burton, L. (2007). Childhood adultification in economically disadvantaged families: A conceptual model. Family Relations, 56, 329-345.

Byng-Hall, J. (2008). The significance of children fulfilling parental roles: implications for family therapy. Journal of Family Therapy, 30, 147-162.

Chase, N. (1999). An overview of theory, research, and societal issues. In N. Chase (Ed.), Burdened children (pp. 3-33). New York: The Guilford Press.

Chase, N., Demming, M., \& Wells, M. (1998). Parentification, parental alcoholism, and academic status among young adults. American Journal of Family Therapy, 25, 105-114.

Cicchetti, D. (2004). An odyssey of discovery: Lessons learned through three decades of research on child maltreatment. American Psychologist, 59, 731-741.

Erikson, E. (1963). Childhood and Society. New York: Norton.

Erikson, E. (1968). Identity, youth and crisis. New York: Norton.

Fullinwider-Bush, N., \& Jacobvitz, D. B. (1993). The transition to young adulthood: Generational boundary dissolution and female identity development. Family Process, 32, 87-103.

Gladstone, B. M., Boydell, C. M., \& McKeever, P. (2006). Recasting research into children's experiences of parental mental illness: Beyond risk and resilience. Social Science and Medicine, 62, 2540-2550. 
Gurba, E. (2002). Wczesna dorosłość [Early adulthood]. In B. Harwas-Napierała \& J. Trempała (Eds.), Psychologia rozwoju człowieka [Psychology of human development] (pp. 202-233). Warsaw: Wydawnictwo Naukowe PWN.

Haxhe, S. (2016). Parentification and related processes: Distinction and implications for clinical practice. Journal of Family Psychotherapy, 27, 185-199. DOI: 10.1080/08975353.2016.1199768

Hooper, L. M. (2007). The application of attachment theory and family systems theory to the phenomena of parentification. The Family Journal, 15, 217-223.

Hooper, L. M., Marotta, S. A., \& Lanthier, R. P. (2008). Predictors of growth and distress following childhood parentification: A retrospective exploratory study. Journal of Child \& Family Studies, 17, 693705. DOI: $10.1007 / \mathrm{s} 10826-007-9184-8$

Hooper, L. M., \& Wallace, S. A. (2010). Evaluating the Parentification Questionnaire: psychometric properties and psychopathology correlates. Contemporary Family Therapy, 32, 52-68.

Hooper, L. M., Doehler, K., \& Hannah, N. J. (2011a). The Parentification Inventory: development, validation and cross-validation. The American Journal of Family Therapy, 39, 226-241.

Hooper, L. M., DeCoster, J., White, N., \& Voltz, M. L. (2011b). Characterizing the magnitude of the relation between parentification and psychopathology: A meta-analysis. Journal of Clinical Psychology, 67, 1028-1043.

Hooper, L. M. (2014). Assessing parentification in South American college students: a factor analytic study of a Spanish version of the Parentification Inventory. Journal of Multicultural Counseling and Development, 42, 93-106.

Jurkovic, G. J. (1997). The plight of the parentified child. New York, NY: Brunner Mazel.

Jurkovic, G. J., Kuperminc, G. P., Perilla, J., Murphy, A. D., Ibanez, G., \& Casey, S. (2004). The role of filial responsibility and cultural ecological processes in school and social adjustment of immigrant Latino adolescents. Journal of Primary Prevention, 25, 81-104.

Klein, D., \& White, J. (1996). Family theories. An introduction. London: Sage Publications.

Kuperminc, G. P., Jurkovic, G. J. \& Casey, S. (2009). Relation of filial responsibility to the personal and social adjustment of Latino adolescents from immigrant families. Journal of Family Psychology, 23, 14-22.

Lackie, B. (1982). Family correlates of career achievement in social work. Ph.D. dissertation, Rutgers University.

Lackie, B. (1983). The families of origin of social workers. Clinical Social Work Journal, 11, 309-322.

Macfie, J., McElwain, N. L., Houts, R. M., \& Cox, M. J. (2005). Intergenerational transmission of the role reversal between parent and child: Dyadic and family systems internal working models. At- tachment \& Human Development, 7, 51-65. DOI: 10.1080/14616730500039663

Namysłowska, I. (2011). Terapia rodzin [Family therapy]. Warsaw: Wydawnictwa Instytutu Psychiatrii i Neurologii.

Nuttall, A. K., Valentino, K., \& Brokowski, J. G. (2012). Maternal history of parentification, maternal warm responsiveness, and children's externalization behavior. Journal of Family Psychology, 26, 767-775.

Obuchowska, I. (2002). Adolescencja [Adolescence]. In B. Harwas-Napierała \& J. Trempała (Eds.). Psychologia rozwoju człowieka [Psychology of human development] (pp. 163-201). Warsaw: Wydawnictwo Naukowe PWN.

Peplińska, A., \& Rostowska, T. (2013). Quality of life and relations between work and family. Acta Neuropsychologica, 11, 77-92.

Radziwiłłowicz, W. (2015). Pomiędzy opuszczeniem, bezpieczną więzią a więzami. Wzorce przywiązania jako kontekst procesu separacji - indywiduacji w okresie dorastania. [Attachment patterns as the contexts of the separation - individualization process during adolescence]. In W. Radziwiłłowicz \& A. Jarmołowska (Eds.), Adolescencja. Wybrane zagadnienia kliniczne i terapeutyczne [Adolescence. Selected clinical and therapeutic issues] (pp. 31-49). Kraków: Biblioteka Psychiatrii Polskiej.

Rostowska, T. (2008). Matżeństwo, rodzina, praca a jakość życia [Marriage, family, work and quality of life]. Kraków: Wydawnictwo IMPULS.

Rostowska, T., \& Borchet, J. (2016). Proces parentyfikacji w kontekście teorii systemowej [The process of parentification in the context of family systems theory]. Roczniki Pedagogiczne, 8, 5-21.

Schier, K. (2010). „Gdy dziecko staje się rodzicem” odwrócona troska, czyli zjawisko parentyfikacji w rodzinie ['When the child becomes the parent' - reversed care, the phenomenon of parentification in the family]. In B. Tryjarska (Ed.), Bliskość w rodzinie. Więzi w dzieciństwie a zaburzenia $w$ dorostości [Closeness in the family. Ties in childhood and adulthood disorders] (pp. 63-80). Warsaw: Wydawnictwo Naukowe Scholar.

Schier, K. (2014). Doroste dzieci. Psychologiczna problematyka odwrócenia ról $w$ rodzinie [The adult children. Psychological problem of reversing roles in the family]. Warsaw: Wydawnictwo Naukowe Scholar.

Shaffer, A., \& Egeland, B. (2011). Intergenerational transmission of family boundary dissolution: Observations and psychosocial outcomes in adolescence. Family Relations: An Interdisciplinary Journal of Applied Family Studies, 60, 290-302. DOI: 10.1111/j.1741-3729.2011.00653.x

Shaffer, A., \& Madden, A. R. (2016). The relation between parentification and dating communication: the role of romantic attachment-related cogni- 
tions. The Family Journal: Counseling and Therapy for Couples and Families, for Couples and Families, 1-6. DOI: 10.1177/1066480716648682

Sęk, H., Ścigała, I., Beisert, M., \& Bleja, A. (1992). Subiektywne koncepcje zdrowia. Wybrane uwarunkowania [Subjective ideas of health. Selected conditions]. Przeglad Psychologiczny, 3, 351-363.

Wells, M., Glickauf-Hughes, C., \& Jones, R. (1999). Codependency: a grass roots construct's relationship to shame-proneness, lower self-esteem, and childhood parentification. American Journal of Family Therapy, 27, 63-71.

Willi, J. (2014). Zwiazek dwojga [Couple relationships]. Warsaw: Wydawnictwo Fundament.

Wojciechowska, L. (2011). Praktyczna wiedza o rozwoju życia rodzinnego [Practical knowledge about family life development]. In J. Trempała (Ed.), Psychologia rozwoju cztowieka [Psychology of human development] (pp. 395-406). Warsaw: Wydawnictwo Naukowe PWN.

Wolska, M. (2000). Rodzinna lojalność [Family loyalty]. In B. Kosek-Nita \& D. Raś (Eds.), Kontakty z ludźmi 'innymi' jako problem wychowania, opieki $i$ resocjalizacji [Contacts with those who are 'different' as a matter of education, care and resocialization] (pp. 49-60). Katowice: Wydawnictwo Uniwersytetu Śląskiego.

Zawadzka, A. M., \& Lewandowska-Walter, A. (2016). Rola wartości i stylów przywiązania w kształtowaniu samooceny i materializmu nastolatków [The role of values and attachment styles in shaping self-esteem and materialism in adolescents]. Polskie Forum Psychologiczne, 21, 394-409.

Ziółkowska, B. (2005). Okres wczesnej dorosłości. Jak rozpoznać potencjał młodych dorosłych? [Early adulthood. How to recognize the young adults potential?]. In A. I. Brzezińska (Ed.), Psychologiczne portrety czlowieka. Praktyczna psychologia rozwojowa [Psychological portraits of a man. Practical developmental psychology] (pp. 423-468). Gdańsk: Gdańskie Wydawnictwo Psychologiczne. 